\title{
Prudential Regulation of the Financial System: A Functional Approach
}

\author{
Warren P. Hogan and Ian G. Sharpe
}

I N announcing the Financial Systems Inquiry on 30 May 1996, Australia's Commonwealth Treasurer (1996) referred to the need for specific recommendations on a number of topics, including the establishment of 'a consistent regulatory framework for similar financial functions, products or services . . '. This reference reflects a very strong current interest in the 'functional' approach to regulation, which Merton (1995) defines as the similar regulatory treatment of economically equivalent transactions.

Several factors have contributed to this interest, including an emerging view that technological developments and financial innovation have stripped banks of their pivotal position in the financial system. Indeed, banks currently do little that is not also done either by financial markets or non-bank financial institutions (NBFIs). Moreover, with the development of financial derivatives, such as options and swap contracts, traditional institutional categories are becoming quite arbitrary.

Financial innovations have also increased competition in financial markets. In the mortgage market, improvements in communications and information technology, along with the development of securitisation, have made it possible for loans to be generated and serviced by institutions different from those that fund them. In Australia, this has resulted in a loss of business for, and pressure on the profitability of, banks and building societies, the traditional mortgage lenders.

The erosion of the distinctions between various participants in Australian financial markets ${ }^{1}$ has been accelerated by the introduction of compulsory superannuation payments for all the workforce. The effect has been to restrict the supply of retail deposits to banks and to increase banks' demand for wholesale deposits where pricing and quantity supplied reflect asset allocations by funds managers. Segmentation of the market for retail funding reflects the previous prohibition, now to be relaxed, on banks bidding directly for superannuation funds by offering special retirement savings accounts. The prohibition encouraged banks to expand their activities into insurance and funds management through subsidiaries. At the same time, insurance companies have expanded into traditional banking activities: for example, Colonial Mutual Group

\footnotetext{
${ }^{1}$ With the increasing integration of world capital markets, these recent developments in financial markets are not unique to Australia. See for example Edwards and Mishkin (1995).
}

Warren Hogan is Professor of Economics at The University of Sydney. Ian Sharpe is Professor of Finance at The University of New South Wales. 
has acquired the State Bank of New South Wales, and AMP has developed its Priority One banking offshoot, which currently offers home-mortgage financing and termdeposit facilities. Thus, financial conglomerates have become increasingly important: approximately two-thirds of the total assets of the Australian financial system are controlled by the 30 largest groups.

These developments, in conjunction with several spectacular failures (and near failures) of financial institutions and other firms active in the new markets, have contributed to a lively debate on whether the changes have affected the stability of the financial system and whether existing financial-sector prudential regulation, which is largely institutionally based, is appropriate to the changed environment. In Australia, the Reserve Bank of Australia (RBA) has responsibility for banks and authorised short-term money market dealers, the Australian Financial Institutions Commission (AFIC) and State Supervisory Authorities for building societies and credit unions, and the Insurance and Superannuation Commission (ISC) for life insurance companies and superannuation and approved deposit funds. Moreover, economists are increasingly concerned that regulation designed to stabilise the financial system and the macroeconomy by preventing runs on financial firms may have had perverse effects.

These concerns have led to proposals to replace the institutionally based system of prudential regulation with a functional approach. The proposals seek to limit the coverage of prudential regulation to key economic functions. Here, we evaluate the purposes and consequences of prudential regulation and then place that analysis in the context of the new functional approach. ${ }^{2}$

\section{Arguments for Prudential Regulation}

The primary economic arguments for prudential regulation, as in other areas of economic regulation, stem from the presence of externalities and/or asymmetric information (Hogan \& Sharpe, 1987, 1990). Positive externalities arise from the acceptance of bank deposits as a medium of exchange and a store of value, but these could be eroded by a bank failure. Moreover, negative externalities would be associated with bank runs if contagion (the effects of shocks on one or more firms spilling over on to others) were to result in solvent banks being impaired and if the real economy were adversely affected. As bank loans are generally risky and difficult to assess or value without careful monitoring, then, in the presence of asymmetric information, depositors may question the value of bank loans in periods of bad economic news. Consequently, deposits could be withdrawn from both solvent and insolvent banks, thereby producing a banking panic. Theoretical justification for this view is provided by Diamond and Dybvig's (1983) model of bank runs, which supports the existence of a

\footnotetext{
${ }^{2}$ Space limitations preclude an analysis of alternative reforms to prudential regulation that have been proposed, such as laissez-faire banking.
} 
regulatory safety net, like deposit insurance or depositor protection. However, the assumptions underpinning the model detract from its applicability.

\section{Systemic Risk}

Controversy surrounds the issue of whether the financial system exhibits instability and, if so, its causes. At one extreme, proponents of laissez-faire banking argue that, in the absence of prudential regulation, market discipline from the bank's owners and creditors would limit the risk assumed by the bank. At the other extreme are those who believe that the financial system is inherently unstable and subject to destabilising financial cycles and crises, and that market forces aggravate recessions (Randall, 1993). They advocate comprehensive regulation of financial institutions so as to prevent excessive risk taking.

The payments clearing system is frequently viewed as an important channel in the spread of financial contagion; since the clearing institutions are closely interconnected, a default by one institution could quickly spread to others. With banks at the centre of the payments system, and given the possibility that financial crises could severely impinge on the efficient operation of the monetary system, the regulatory safety net has traditionally focused on banking activities. However, the introduction of new arrangements for payments between banks later in 1997 will see requirements for the instantaneous payment of obligations due to other banks. These provisions have the potential to reduce significantly the payments-related credit risk exposures of individual banks, with a consequent reduction in systemic risk (see RBA, 1995).

Kaufman (1994) concludes that the costs of bank failures are relatively small and that bank runs are largely firm-specific and a rational response to relevant information. Furthermore, systemic risk (the risk of widespread contagion) is significantly reduced when monetary authorities act to restore aggregate banking system reserves that would otherwise be reduced in a flight to currency. The Australian experience of the 1987 stock market crash lends support to this view.

Nevertheless, most countries have introduced regulatory safety nets such as lender-of-last-resort arrangements, deposit insurance schemes and, in Australia, a combination of government guarantees, the depositor protection provisions of the Banking Act, prudential arrangements for building societies and credit unions under the AFIC, and supervision of insurance and superannuation under the ISC. The objectives of the safety nets are to reduce systemic risk, to protect depositors/investors deemed to be disadvantaged in their ability to protect themselves in the presence of asymmetric information, and possibly to provide economies of centralised risk monitoring. An alternative view is that the best protection against systemic risk is stable

3

${ }^{3}$ Schwartz (1995) notes that Diamond and Dybvig's bank is a monopoly bank with no capital and that there is no central bank in the model. In the absence of a regulatory safety net, rational banks will structure their operations so as to limit the probability of a run on deposits by holding capital to reassure depositors of the safety of their deposits. Moreover, in a multi-bank system a withdrawal from one bank is likely to be redeposited in another rather than being taken in cash, while flights to currency could be limited by open-market operations of the central bank. 
macroeconomic policies. However, Kaufman (1996) argues that because central banks are unlikely to deliver such policies successfully, a back-up prudential safety net is desirable.

\section{Moral Hazard and Principal-Agent Problems}

When they are unfunded, or financed by an implicit or explicit fixed risk-insensitive charge (or deposit insurance premium), safety nets introduce new problems. The most important of these is moral hazard. Assuming the safety net is credible, banks have an incentive to increase shareholder value by increasing risk (for example, with a more risky asset portfolio and/or a lower capital ratio) because they no longer have to pay a risk premium on their deposits and the risk of a run of those deposits is significantly reduced. In effect, the risk is shifted from depositors to the deposit insurer/protector, and ultimately to general taxpayers. Thus, the safety net provides a taxpayer-funded subsidy to bank-equity holders for increased risk taking.

To overcome the moral hazard problem and thereby limit the taxpayer-funded subsidy of excessive bank risk taking, governments implement various types of prudential regulations and controls through central banks or other regulatory agencies. These regulations replace the forgone market discipline with regulatory discipline. However, there is little evidence supporting the view that governments or their regulatory agencies are more efficient than market participants in assessing changes in risk in a timely manner and in taking appropriate disciplinary actions (Benston, 1993:69-73; Hogan \& Sharpe, 1991).

Another problem introduced by regulation is the principal-agent problem, where regulators acting as agents for taxpayers may pursue their self-interest rather than the public interest. Prudential supervision is a discretionary form of regulation that relies on judgment and ambiguity to eliminate perverse moral hazard incentives. Boot and Thakor (1993) note that supervisors perform two roles: (i) monitoring and supervising bank risk or asset choice where the supervisor's ability is uncertain; and (ii) deciding whether a problem bank should be closed. They show that regulators acting in their self-interest have an incentive to delay closing problem banks because the closure damages the regulator's prestige and reputation as an efficient supervisor of bank risk. Furthermore, because regulators are criticised for bank failures and do not get the full benefit of bank risk taking, they have an incentive to adopt an overly conservative policy toward bank risk taking. This conservative position is further compounded by their lack of confidence in the ability of monetary policy to counter systemic risk through appropriate open-market operations.

Prudential policy must attempt to balance two objectives: systemic stability, and minimising taxpayer-funded losses of failed banks arising from the moral hazard problem for banks and the principal-agent problem for regulators. However, the two

\footnotetext{
4 The view that moral hazard underlies increased risk taking in banking has not gone unchallenged. Gorton and Rosen (1995) note that the increased risk has emanated from loan portfolios where shareholders rely on managers' lending decisions and where asymmetric information makes the monitoring of these decisions costly.
} 
objectives are time-inconsistent in, for example, the decision of whether to bail out a troubled bank. While a bailout may have a positive immediate benefit in preventing a single bank default from having systemic consequences, it does so at a longer-run cost of increasing moral hazard for banks because the bailout reduces both the incentive of creditors to monitor the risk of banks and the incentive of banks to maintain solvency (see Lane, 1993).

\section{Market Discipline and Credibility}

Effective market discipline of risk taking by banks and NBFIs requires that:

1. financial markets are competitive;

2. timely and reliable information on the institution's prudential condition is available for shareholders, creditors and/or private risk-rating agencies;

3. shareholders and creditors believe that the institution will not be bailed out if it is insolvent; and

4. financial markets correctly signal changes in risk exposures and shareholders and creditors respond appropriately to those signals.

In Australia, the first condition for market discipline does not appear to be a problem, though mergers between the major banking groups and/or major insurance groups would require a reassessment. Discussions relating to the information condition have suggested three potential improvements to information flows: (i) making supervisor's on-site examination reports publicly available; (ii) the use of market value accounting; and (iii) risk accounting techniques which Merton (1995:26) describes as measures to indicate 'how individual balance sheet values are likely to change in response to changes in the underlying financialeconomic environment'. An improvement in the quality of information reduces asymmetric information and systemic risk as market participants would be better able to differentiate between the risk attributes of individual borrowers.

However, improved information is of little benefit to market participants if they do not believe their investments are at risk. Hence the third condition for market discipline, the no-bailout condition, is critical. Here the issue is one of credibility, for it is not enough for a regulator or government to promise there will be no bailout: it must be credible.

A regulatory promise to close insolvent institutions in a timely and efficient manner with shareholders and creditors at risk is generally thought to be less credible when the depositors/creditors are viewed as being relatively unsophisticated small in-

\footnotetext{
objectives. However, the principal-agent problem for regulators is also of some relevance.
} 
vestors, when the institution plays a key role in the operation of the payments system so that systemic risk is of greater concern, and/or when it is perceived as being so big that regulators would not allow it to fail. The latter possibility, commonly referred to as 'too big to fail' (TBTF), is particularly serious as it introduces regulatory inequity." That is, large institutions are granted a competitive advantage in accessing funds in financial markets, while smaller institutions have to pay higher risk premiums on those borrowings because they are not underwritten or subsidised by the TBTF policy.

The fourth condition for market discipline relates to the ability of markets to signal changes in risk exposures and whether bank management take prudent actions as a consequence. There is now strong evidence ${ }^{7}$ to show that bank share prices reflect bank risk and that yields on bank-subordinated debt and certificates of deposit incorporate risk premiums. However, the evidence is less clear that bank management responds to those signals by reducing risk without regulatory supervision.

This analysis suggests that there would be considerable scope for utilising market discipline to limit the moral hazard and principal-agent problems without significantly compromising the objective of systemic stability. The recent reforms to banking supervision in New Zealand involve a very significant shift towards a reliance on private sector market-based discipline to supervise bank risk taking (see Grimes, 1996).

\section{The Financial Sector's Six Functions}

The functional approach to the analysis of the activities pursued within the financial sector draws its inspiration from the stability in the services offered over time by its various participants. This feature contrasts with the institutional arrangements within the financial sector whereby legal entities can take on new functions while possibly discarding old ones. This distinction between the stability of functions and the flexibility of the participating institutions in the financial sector is important in assessing where regulatory monitoring and supervision might help secure optimal outcomes.

The main purpose of the financial services sector is to support the allocation of real goods and services within and between economies. Within this primary purpose, it is possible to distinguish six basic functions undertaken within the financial sector (Merton \& Bodie, 1995).

Clearing and settlement. The main feature of this function is the payments system whereby the exchange of goods, services, assets and liabilities is completed. This payments or clearing system may be treated at different levels. Conventionally, the dominant characteristic has been the electronic and paper transfers between banks

\footnotetext{
${ }^{6}$ A referee has commented that large institutions may secure economies of scale in risk management. However, a recent review of US bank economies of scale studies by Berger et al. (1993) concluded that medium-sized banks were slightly more scale-efficient than either very lange or very small banks. For Australian evidence, see Esho and Sharpe (1995).

${ }^{7}$ For Australian evidence, see Dennis, Sharpe and Sim (1996), and, for the US, Gilbert (1990), Ellis and Flannery (1992) and Cook and Spellman (1994).

8

Information may not be absorbed promptly or accurately by market participants on all occasions; but such a reservation applies equally to regulatory and rating-agency responses to information.
} 
through settlement accounts at the Reserve Bank of Australia. The efficient use of this mechanism has called forth a number of financial techniques, including collateral provisions, daylight overdrafts and interbank funding. Furthermore, clearing and settlements come in other guises, such as clearing houses for exchange-traded derivative financial instruments.

Pooling and divisibility. The financial sector provides the means for bringing together funds held by households and firms, thus allowing the pooling of individual sums to support an array of productive activities. Mechanisms for pooling resources and subdividing shares may be found in intermediation and securitisation.

Resource transfers. This function relates to the transfer of economic resources in time and location. This means life-cycle allocations by households and optimal allocation of capital resources in efficient locations of plant and equipment. The great bulk of financial intermediaries and agents participate in these activities.

Risk management. This function is about managing uncertainty and controlling risk. It is a comparatively new development as a separate function, allowing distinctions to be made between real investment and risk bearing. The growth of financial derivatives has extended greatly the scope for hedging risk and at the same time provided further means of separating savings functions from risk-avoidance measures.

Information. With the main purpose of financial markets to foster transactions in financial instruments, the information on which to base decisions for market participation is generated by both price and the volume of trades taking place. At issue is the extent to which such information helps assessments about future prices and their volatility. The scope for drawing inferences of this nature has been extended by the rapid growth of new financial instruments over the past two decades, most notably with derivatives and swaps.

Incentives, contracting and completion. An effective financial system provides the means to minimise incentive problems between parties to contracts. This means that parties have as much common information as possible so that each may observe and recognise the action of others. The result is to reduce, if not eliminate, enforcement costs.

\section{Functions and Prudential Regulation}

At issue is the breadth of the canvas for the conduct of prudential regulation and what that regulation should embrace. Present arrangements differ from country to country, but most reflect some formal measure of depositor protection. In Australia, the Banking Act provides for the RBA to be 'the guardian, not the guarantor of depositors' interests' (Johnston, 1985:571). Thus, for prudential purposes, the main focus of monitoring and supervision is the protection of depositors. 
There is one function on which the other five depend for the completion of all financing activities: clearing and settlement. This function is becoming increasingly dominant, reflecting the extension of clearing from the banking institutional setting in a variety of ways. Households are linked to payments clearing directly rather than indirectly through the historic paper settlement and clearing. The range of institutional clearers has been extended by inauguration of exchange-traded clearing, particularly for derivative financial instruments. This capacity to complete financial transactions with certainty stands as the most important feature of the financial services sector. It is essential to the efficient performance of the real sectors in the economy. By the same token, households and business entities wish to ensure certainty in the completion of agreements or contracts to buy those goods and services. Accordingly, there are firm grounds for adapting institutions to meet this need for safety and certainty in clearing and settlement.

There are two possible ways of implementing the functional approach. The more radical way is to define banks as those institutions offering only transactions accounts and payment services backed by safe assets (Pierce, 1993). Many financial institutions, other than those now defined as banks, might be enticed or persuaded to become banks under this regime. This radical proposal to confine banking to transactions services for clearing and settlement would be based on liabilities other than shareholders' funds being held in short-term liquid assets, mainly federal or State government bonds and treasury bills. More important would be the holding of foreign governments' short-term bonds and treasury bills to ensure liquidity in international clearing. Liabilities would comprise the transaction deposits of the funancial system. Any individual or entity wishing to participate in clearing and settlements would have to hold a deposit account with a transactions bank. To secure funds to meet a payment when insufficient sums were lodged in the deposit account, the user would have to borrow from a non-bank financial intermediary to ensure availability of funds for completion. The bank, in its turn, would have to manage its asset portfolio to ensure the availability of funds to meet claims in the clearing and settlements system. Provision would be needed to permit borrowing from outside transactions banking to ensure liquidity and thus capacity to meet the needs of clearing and settlement. Thus, any transactions bank would be able to borrow from, but never lend to, other non-bank financial institutions.

In exchange for the limitations on access to the payments system for clearing and settlement, what sort of guarantee would depositors enjoy for the safety and certainty of their accounts? Pierce (1993) argues for specific guarantees of all transaction bank deposits: all those wanting fully guaranteed deposits would lodge their funds in transactions accounts matched by government paper. This guarantee by government, through the central bank as the supervisor, would not apply to any other type of deposit or its equivalent. The effect of this arrangement is to distinguish the transactions role of demand deposits from the other five functions, which are a reflection of investment activity.

To prevent moral hazard, Pierce (1993) would heavily regulate the transactions banks with asset restrictions, risk-based capital standards, and strong prudential regu- 
lation and supervision. In contrast, the financial institutions not classified as transactions banks would not be recipients of deposit guarantees and hence would not be subject to prudential regulation. Instead, they would be subject to companies law and disclosure requirements.

An alternative proposal for implementing this functional approach would be to require all institutions wishing to engage in clearing and settlement, whether they be banks (as now defined by the Banking Act), building societies, credit unions or other financial entities, to account separately for transactions services activities within the structure of their corporate accounts (see Merton \& Bodie, 1993). The same structures would apply as with the radical approach, namely, the matching of demand deposits with short-dated bonds and treasury bills from domestic governments and, possibly, foreign-government paper with similar maturities and liquidity. However, somewhat watered-down proposals have been advanced that would allow transaction banks to include top-quality business paper and loans as collateral on transactions deposits.

\section{Evaluation of Transactions Banking}

Regulatory equity. The crux of the functional approach is the distinction between transactions banking business and all other financial activities. The former is geared up to supervision and monitoring in light of the commitment to guarantee transactions deposits. The latter group, heterogeneous as it is in its institutional complexity, is not subject to any guarantees or prudential protection. In short, there is a heavy stress on the role of market discipline in all financial activities other than transactions banking. The explanation for this sharp distinction is straightforward. Once the remaining five functions of the financial services sector are analysed, it is hard to discem any specific qualities in the assets and liabilities of any one set of financial institutions which are separable from those exhibited by other sets. There are many other deposit-taking intermediaries besides banks, while the growth of trusts and investment funds has brought many different ways of mobilising savings. Moreover, finance companies and money market corporations play significant roles in business lending. In these circumstances, there is no ready justification for continuing traditional distinctions between banks and other financial intermediaries in order to limit deposit guarantees, other than in their transactions role.

Because the functional approach applies regulation to economic activities, it achieves regulatory equity within functions. Thus, transactions banking proposals would eliminate many of the distortions and inefficiencies emanating from existing institutionally based regulation.

\footnotetext{
9 Pierce (1993) would also allow for some insurance regulation to continue.

10

Alternatively, equity could be achieved by extending existing guarantees and prudential regulation so as to encompass all forms of financing and financial institutions. However, the further extension of such guarantees calls into question the potential costs of support and its implications for taxpayers.
} 
Systemic risk. The traditional argument for some type of guarantee for all bank deposits is that banks typically convert short-term liabilities into illiquid long-term assets. At any one time, there is the risk of not being able to re-finance an asset portfolio while at the same time not being able to run down quickly a loan portfolio so as to match the claims for repayment. This possibility opens up not just the prospect of illiquidity leading into failure, but also the potential for contagion as closure of one bank may bring runs on the liquidity of other banks.

Being withdrawable on demand, transactions deposits are much more susceptible to runs than time or fixed deposits. Thus, provided non-transactions banks are precluded from paying out their fixed deposits prior to maturity, the functional regulatory proposals focus the government guarantee on those depositors with the greatest capacity to withdraw funds at a time of crisis. Those insured depositors include the relatively less well-informed depositors who traditionally hold transactions deposits in banks, building societies and credit unions. Moreover, the guarantee is buttressed by asset allocation restrictions and prudential regulation and supervision which would severely limit risk taking in transactions banks. With these protections, there is little prospect of default on deposits, or of runs and illiquidity crises, within the transactions banking area. Furthermore, the development of real-time payments settlement systems has the potential to reduce significantly credit risk arising from non-instantaneous settlement between participants in the payments system.

Nevertheless, there remains a concern, particularly among regulators, that systemic risk and contagion may develop in the non-transactions banking area. But Kaufman's (1994:132) survey of US studies finds little evidence of contagion among money market funds, finance companies or security brokerage firms surrounding the failure of a firm in the industry. The extension of the safety net beyond transaction banking is, therefore, unlikely to reduce significantly systemic risk in the financial system.

Credibility and moral hazard. The functional regulatory proposals offer scope for a significant reduction in regulation-induced moral hazard within the financial system by focusing regulation on transaction banking while enhancing market discipline in the non-transactions sphere. But would prudential regulation reflecting this distinction be credible?

At issue is whether creditors or investors in the non-transaction sector believe that regulatory authorities would not, under any circumstance, support a financial intermediary experiencing difficulties when that institution is not an authorised transaction bank. Three circumstances could result in regulatory intervention and a bailout of depositors: where the institution is considered to be so big that the authorities fear the ramifications of its failure on financial markets; where the institution has many small and relatively unsophisticated depositors capable of exerting political pressure; and where the troubled institution is part of a major financial group in which there is also a transaction bank.

While one can never be certain that the authorities would not implement a TBTF policy, the fact that the payments system would be insulated from runs could reduce 
regulatory fears of systemic dangers. Moreover, the functional approach would fully protect the transactions balances of small unsophisticated depositors who currently conduct their payments transactions through banks, building societies and credit unions. The third circumstance questions the effectiveness of the so-called Chinese walls that would have to be established between the transaction bank and subsidiaries in the non-transaction sector. But this issue is not new, having been addressed in a related way in the RBA's Prudential Statement No. C2 on funds management and securitisation (RBA, 1994). Apart from legal obligations, the non-banking activity must be held separate from that of the bank within the group and investors must be made fully aware that their investments are subject to investment risk, and do not represent deposits or other liabilities of the banking group.

A related issue is how the transaction bank should be organised in a group of legal entities. There are grounds for thinking that the radical transactions banking proposal must imply a holding company structure with the transactions bank a subsidiary. It could not be the parent company of the group, as is presently the case for most Australian banks.

Other considerations. The restriction preventing transactions banks from engaging in personal and business lending has created some concern that the supply of these loans may be reduced. Given the trend toward securitisation of large business loans and home mortgage loans, there is little need for concern in these two areas. Of more concern is the potential effect on small to medium business lending; but even then it must be noted that finance companies and money market corporations lend actively in this area and do so without government guarantees. Hence there is every reason to expect that banking groups would continue providing lending services to small businesses, but through a non-banking subsidiary.

The transactions banking proposal is also attractive for its affinity to trends in financial markets. With the unbundling of services and gradual removal of crosssubsidisation of banking services, transactions banking has become a profit centre within banks. Hence the separation of transactions banking from other services could be viewed as a natural evolution of current banking trends. Where it breaks new ground is in the restriction of asset choice to protect the transaction deposits. Moreover, securitisation in the mortgage market is breaking down the traditional practice of funding mortgages with short-term liquid demand deposits. It is inevitable that corporate lending will also move in this direction. The functional banking proposals appear to offer the prospect of accelerating the elimination of existing cross-subsidies in transactions banking.

When assessing the practicality of the transactions banking proposal in its various guises, one should examine just what banks now do in the payments system. Trans-

\footnotetext{
11 A colleague has suggested that funding loans with non-transaction deposits could increase interest rates on those loans. However, this need not be the case as borrowers presently cross-subsidise some transaction banking activities. In the narrow banking model these cross-subsidies would be eliminated, allowing some reduction in existing borrowing rates.
} 
actions-related items in a major bank's balance sheet show items due to and from other banks. For example, in 1995 National Australia Bank had about 4.9 per cent of its assets in the 'Due from' category and 9.5 per cent as 'Due to'. There is a substantial commitment to short-term credit in support of the payments systern. Moreover, within any one bank group there are substantial proportions of assets and liabilities in the bank related to intragroup transactions; 10.5 per cent and 6.3 per cent respectively for the National Australia Bank in 1995. Much of this would have to be taken outside transactions banking under any functional proposal. However, as noted earlier, with the introduction of real-time payments settlement, these proportions of balance sheet business should be reduced.

\section{Conclusion}

Prudential regulation involves a trade-off between the policy objectives of ensuring systemic stability and of minimising the taxpayer-funded subsidy of bank risk that arises from the moral hazard and principal-agent problems. Recently, more stable monetary policy techniques have reduced systemic risk concerns, while regulatory failures in the US and elsewhere have highlighted the costs generated by the moral hazard and principal-agent problems. Consequently, numerous reform proposals have been advanced with the objective of reducing the agency costs by replacing regulatory discipline with market-based discipline.

We have provided an economic analysis of one of those proposals: functional regulation. Within this proposal, concerns for systemic risk underlie the provision of a guarantee for deposits in transactions banks and the associated prudential regulation of those deposits. Moreover, by restricting the regulatory safety net to transactions banking, moral hazard is confined to these activities, while allowing market discipline, supported by adequate disclosure requirements, to constrain risk taking in the remainder of the financial system.

Our economic analysis of this functional approach suggests that it could have considerable merit. But this would require market discipline to operate effectively in the non-regulated sector of the financial system. This requirement is dependent on two conditions. First, there must be a policy whereby the government and/or central bank does not bail out those financial institutions beyond transactions banking, should they experience financial difficulties. Second, this policy must have credibility with market participants.

\section{References}

Benston, G. (1993), 'Market Discipline: The Role of Uninsured Depositors and Other Market Participants', pp. 65-95 in R. Randall (ed.), Safeguarding the Banking System in an Environment of Financial Cycles, Federal Reserve Bank of Boston (Conference Series No. 37).

Berger, A., W. Hunter \& S. Timme (1993), 'The Efficiency of Funancial Institutions: A Review and Preview of Research Past, Present, and Future', Joumal of Banking and Finance 17: 221-49. 
Boot, A. \& A. Thakor (1993), 'Self-interested Bank Regulation', American Economic Review 83: 206-12.

Cook, D. \& L. Spellman (1994), 'Repudiation Risk and Restitution Costs: Toward Understanding Premiums on Insured Deposits', Joumal of Money, Credit and Banking 26: 439-59.

Dennis, S., I. Sharpe \& A. Sim (1996), 'Implicit Deposit Insurance and Deposit Guarantees', unpublished manuscript, School of Banking and Finance, University of New South Wales, Sydney.

Diamond, D. \& P. Dybvig (1983), 'Bank Runs, Deposit Insurance, and Liquidity', Joumal of Political Economy 9: 445-52.

Edwards, F. \& F. Mishkin (1995), 'The decline of traditional banking: implications for financial stability and regulatory policy', FRB of New York Economic Policy Review 1: 27-42.

Fllis, D. \& M. Flannery (1992), 'Does the Debt Market Assess Large Banks' Risk?', Journal of Monetary Economics 30: 481-502.

Esho, N. \& I. Sharpe (1995), 'Long-run Estimates of Technological Change and Scale Economies in a Dynamic Framework: Australian Permanent Building Societies, 1974-1990', Journal of Banking and Finance 19: 1135-57.

Gilbert, R. (1990), 'Market Discipline of Bank Risk: Theory and Evidence', FRB of St Louis Review 72: 3-18.

Gorton, G. \& R. Rosen (1995), 'Corporate Control, Porffolio Choice, and the Decline of Banking', Journal of Finance 50: 1377-420.

Grimes, A. (1996), 'Public Standards and Private Monitoring. New Zealand's New Banking Supervision Regime', Agenda 3(3): 277-86.

Hogan, W. \& I. Sharpe (1987), 'Some Issues in Prudential Regulation and Examination', pp. 386-98 in D. Jüttner \& T. Valentine (eds), The Economics and Management of Financial Institutions, Longman Cheshire, Melbourne.

(1990), 'Prudential Supervision of Australian Banks', Economic Record 66: 127-45.

- (1991), 'Market Discipline and Prudential Supervision: Procedures and Prospects in Australia', pp. 118-42 in C. Kearncy \& R. Macdonald (eds), Developments in Australian Monetary Economics, Longman Cheshire, Melbourne.

Johnston, R. (1985), 'Prudential Supervision of Banks', Bulletin, Reserve Bank of Australia (March): 571 5.

Kaufman, G. (1994), 'Bank Contagion: A Review of the Theory and Evidence', Journal of Financial Services Research 8: $123-50$.

__ (1996), 'Bank Failures, Systemic Risk, and Bank Regulation', Federal Reserve Bank of Chicago, Issues in Financial Regulation (Working Paper Series No. WP-96-1).

Lane, T. (1993), 'Market Discipline', IMF Staff Papers 40: 53-88.

Merton, R. (1995), 'Financial Innovation and the Management and Regulation of Financial Institutions', NBER, Cambridge, Mass. (Working Paper Series No. 5096). 
— \& Z. Bodie (1993), 'Deposit Insurance Reform: A Functional Approach', pp. 1-34 in A. Meltzer \&

C. Plosser (eds), Camegie-Rochester Confenence Series on Public Policy No. 38.

— \& Z. Bodie (1995), 'A Conceptual Framework for Analyzing the Financial Environment', pp. $3-31$ in D. Crane, K. Froot, F. Mason, A. Perold, R. Merton, Z. Bodie, E. Sirri, \& P. Tufano, The Global Financial System: A Functional Perspective, Harvard Business School Press, Boston.

Pierce, J. (1993), 'The Functional Approach to Deposit Insurance and Regulation', pp. 111-30 in R. Randall (ed.), Safeguarding the Banking System in an Environment of Financial Cycles, Federal Reserve Bank of Boston (Conference Series No. 37).

Randall, R. (1993), 'Safeguarding the Financial System from Financial Cycles', pp. 17-64 in R. Randall (ed.), Safeguarding the Banking System in an Envinonment of Financial Cycles, Federal Reserve Bank of Boston (Conference Series No. 37).

Reserve Bank of Australia (RBA) (1994), 'Funds Management and Securitisation', Prudential Statement No. C2, Sydney.

(1995), 'Reform of Interbank Payments: RTGS Business Specifications', Press Release, Sydney (31 August).

Schwart, A. (1995), 'Coping with Financial Fragility: A Global Perspective', Joumal of Financial Services Research 9: 197-208.

Treasurer (1996), 'Financial System Inquiry - Terms of Reference and Membership', Press Release No. 19, Canberra (30 May).

An extended version of this article is available from the authors. The authors wish to thank James Bartle, Kevin Davis, Peter Docherty, Neil Esho and two anonymous referees for helpful comments on the previous draft. 